\title{
Erratum to "Pedigree verification and parentage assignment using genomic information in the Mexican Holstein population" (J. Dairy Sci. 102:1806-1810)
}

\section{A. García-Ruiz, G. R. Wiggans, and F. J. Ruiz-López}

The title of the research project was incorrect in the Acknowledgments. The first sentence of the Acknowledgments should read (correction in bold): This study was supported by Consejo Nacional de Los Recursos Genéticos Pecuarios, Instituto Nacional de Investigaciones Forestales, Agricolas y Pecuarias (Ciudad de México, México), research project 19133933989 "Impact of Foreign Information on the Genetic Evaluation of Mexican Holstein Sires."

The journal regrets the error.

\section{REFERENCES}

García-Ruiz, A., G. R. Wiggans, and F. J. Ruiz-López. 2019. Pedigree verification and parentage assignment using genomic information in the Mexican Holstein population. J. Dairy Sci. 102(2):1806-1810. https://doi.org/10.3168/jds.2018-15076. 